\title{
Effect of Proteolytic Enzymes on The Biological Degradability of Gelatin-Based Films
}

\author{
Bakyt B. Tyussyupova, Sagdat M. Tazhibayeva, Kuanyshbek Musabekov,Yessengeldi Mussatay, Azymbek Kokanbaev \\ Al-Farabi Kazakh National University,
}

\begin{abstract}
Biodegradable films based on gelatin were obtained. Glycerine is used as a plasticizer of films. The effect of proteolytic enzymes: pepsin and chymosin on the biodegradability of films was studied. It is shown that the specific activity of pepsin in relation to gelatin films is higher than that of chymosin. Structural and mechanical characteristics of gelatin films in the presence of pepsin and chymosin were determined. It is shown that with an increase in the concentration of enzymes, the strength, modulus of elasticity and deformation increase, which indicates the softening and decomposition of films. The destructive effect of enzymes on gelatin films is also shown by the change in the roughness of the films, which increases in the presence of enzymes, especially in the case of pepsin
\end{abstract}

Keywords: biodegradability, film, polymer, enzyme, strength, roughness.

\section{INTRODUCTION}

The development of new biodegradable polymer materials for packaging intended for use in industry, agriculture, and medicine is an urgent problem of modern science. At the same time, the preservation of the environment comes to the fore for manufacturers of packaging materials.

A radical solution to the problem of environmental pollution with polymer waste from synthetic materials used as packaging and agricultural films - can be the creation of polymers that can undergo biodegradation $[1 ; 2 ; 3]$.

These include biopolymers, [4]. obtained directly from natural materials such as polysaccharides (starch, cellulose), proteins (casein, silk); manufactured by chemical synthesis from monomers obtained from renewable raw materials (polylactic acid); produced by microorganisms or genetically modified bacteria (polyhydroxyalkanoate, polyhydroxy-butyrate). The main advantages of replacing traditional polymers obtained from oil refining products with natural polymers are their biodegradability and renewability $[4 ; 6]$.

The biodegradable material can be decomposed in natural conditions: in aerobic or anaerobic conditions under the action of microorganisms, ultraviolet light, radiation, which further leads to the absorption of this material by microbes [8]. Most often, the decomposition products are carbon dioxide, water, and biomass (in the case of anaerobic decomposition, carbon dioxide, methane, and biomass), which are naturally disposed of in nature [9]. In this regard, new packaging materials are constantly being developed, which quickly disintegrate and are easily assimilated by soil microorganisms, without harming the environment.

One of the directions for obtaining biodegradable materials is to obtain compositions using the natural polymer gelatin. However, the determination of the ability of materials to biodegradation under natural conditions is a continuous process. In this regard, the development of express methods for determining the biodegradability of materials is relevant. At the same time, the use of enzymes for these purposes is promising, since in natural conditions they play a crucial role in the decomposition of materials.

Enzymes are biocatalysts of chemical processes, they are biologically active proteins that function in conditions favorable for the life of the organisms from which they are isolated. Modern biotechnologies make it possible to obtain pure enzyme preparations of specific action in an amount sufficient for industrial use. The protein nature of the enzymes provides mild conditions for the catalyst, allows to regulate the technological process by varying the operating parameters of production, and helps to save resources and energy. The biodegradability of enzyme preparations at the disposal stage and the absence of toxicity improve the environmental safety of production [10].

The unique properties of enzymes that can catalyze chemical transformations under mild conditions with a high degree of substrate specificity have made it possible to use them widely. Currently, enzymes are widely used in the food industry [12; 13], medicine and pharmaceutical industry [14], agriculture [15], fine organic synthesis, [16]. etc. Despite significant advances in the study and application of enzymes, an intensive search for new sources of enzymes and a detailed study of their catalytic properties continues.

Like all proteins, enzymes are polypeptides that are packaged in a very specific way. Based on the study of the chemical structure of various enzymes and mechanisms of their action on the substrate, that is, the starting material is converted under the action of the enzyme in product, it was found that in contact with the substrate enters only a small portion of the enzyme called the active site, consisting typically of 5-10 amino acid residues [17]. In the active center of the enzyme, two sites are distinguished, namely, the catalytic site, which is responsible for the direct function of the enzyme, and the contact or "anchor" site, which provides a specific affinity and formation of the enzyme-substrate complex.

The main feature of enzyme reactions is that they occur as 
part of an active complex resulting from the binding of the substrate to the catalytic center of the enzyme molecule, to which the substrate has a specific affinity. As a result of the formation of such a complex, the activation energy of the chemical reaction is significantly reduced, which makes possible a faster course of the catalytic transformation. Thus, the mechanism of action of enzymes can be considered from two positions: from the point of view of changes in the energy of chemical reactions and from the point of view of processes in the active center of the enzyme molecule [18].

The aim of this research is to study the effect of proteolytic enzymes - pepsin and chymosin - on the formation and destruction of biofilms containing gelatin.

\subsection{Experimental part}

Available biopolymer - food gelatin (Kazakhstan, "Royal Food") was used to produce films. As a plasticizer, food glycerin was used (Kazakhstan, "Pharmacy").

Proteolytic enzymes such as pepsin and chymosin were used to cleave the films.

Pepsin is a globular protein with a molecular weight of about 34500 (Japan, "Meito Sangyo Co., Ltd"). The pepsin molecule is a polypeptide chain that consists of 340 amino acids, contains 3 disulfide bonds $(-\mathrm{S}-\mathrm{S}-$ ) and phosphoric acid. Pepsin cleaves central peptide bonds in protein and peptide molecules to form simpler peptides and free amino acids [19]. It is formed from its precursor pepsinogen, produced by the main cells of the gastric mucosa [20]. It is present in the gastric juice of humans, mammals, and birds.

Chymosin (rennin) is a proteolytic enzyme belonging to the class of aspartate proteinases (Ukraine, "Miltex"). It is an enzyme of the hydrolase class that catalyzes the hydrolysis of peptide bonds formed primarily by hydrophobic amino acid residues. It is obtained in crystalline form, with a molecular weight of 40000 [21]. Chymosin - an enzyme of animal origin, found in the mucous membrane of the third stomach of ruminants. Like other aspartate proteinases, chymosin is synthesized by the gastric mucosa of newborn mammals as an inactive precursor, prohymosin [22].

To obtain films, $100 \mathrm{ml}$ of aqueous solution containing $5 \mathrm{~g}$ of gelatin, $2 \mathrm{~g}$ of glycerol plasticizer and $0.1 \mathrm{~g}$ of enzyme was heated with stirring to $60-70^{\circ} \mathrm{C}$, poured onto a plastic substrate and left for 24 hours at $25^{\circ} \mathrm{C}$. Then the films were separated from the substrate and the strength characteristics of the films were determined.

Spectrophotometric studies to determine the activity of enzymes were performed on a UV-7504 spectrophotometer (China) with a measurement accuracy of $\pm 2 \%$.

To study the effect of enzymes on the biodegradability of gelatin films, $0.05 \mathrm{~g}$ of the film was dissolved in $6 \mathrm{ml}$ of water solutions of pepsin and chymosin, the specific activity of the enzyme was calculated according to [23].

The determination of tensile stress and elongation at break of the films was carried out using an MT 150 tensile testing machine (Russia).

The elemental composition of films obtained in the presence of enzymes was determined by $\mathrm{x}$-ray fluorescence analysis using the XRF 8680 device (Belarus).

Changes in the surface roughness of films under the influence of added enzymes were studied using multifunctional automated systems (Integra Spectra, AFM-Raman-SNOMTERS (Russia).

\section{RESULTS AND DISCUSSION}

Currently, the processes of enzymatic catalysis are of great interest for solving a number of scientific and practical tasks. The unique properties of enzymes that can catalyze chemical transformations under mild conditions with a high degree of substrate specificity have determined their application in many technological and analytical processes, such as in the food industry, pharmaceuticals, medicine, in the creation of biosensors, in the processes of fine organic synthesis, etc [24].

Enzyme preparations are characterized by specific activity, which reflects the degree of purification of the enzyme. Specific activity is the number of enzyme activity units per 1 $\mathrm{mg}$ of protein [23].

The spectrophotometric method allows measuring the rate of the enzymatic reaction by changing the absorption of the substrate at the characteristic wavelength. Light absorption was measured for the protein enzymes pepsin and chymosin in the wavelength range of 220-350 $\mathrm{nm}$ (Figure 1). The maximum and minimum values of light absorption are revealed. Since protein enzymes consist of residues of various amino acids, the minimum absorption value corresponds to $220 \mathrm{~nm}$, and the maximum absorption value corresponds to $290 \mathrm{~nm}$, which is consistent with the literature data [25].

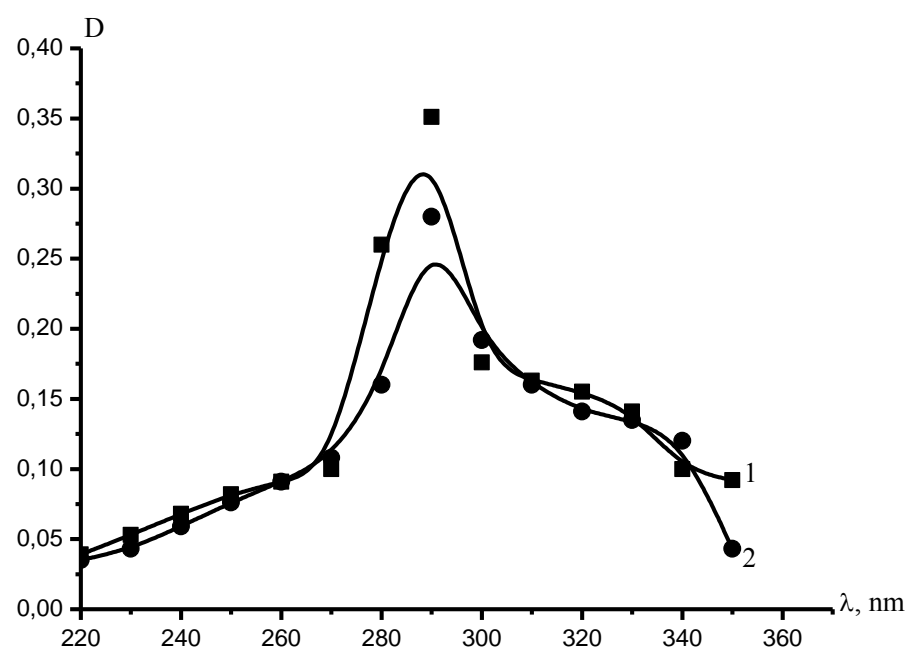

Figure 1: Dependence of the optical density of pepsin (1) and chymosin (2) solutions on the wavelength

Measuring the optical density of pepsin and chymosin 
solutions after contact with gelatin-glycerin films at wavelengths of 220 and $300 \mathrm{~nm}$ allowed calculating the specific activity of the enzyme. As can be seen from Figure 2, the specific activity of pepsin is higher than that of chymosin. Pepsin differs from other enzymes in that it does not have strict specificity, so it can destroy all the peptide bonds in the macromolecules of gelatin amino acids. Chymosin can only destroy the peptide bonds of gelatin that were formed using hydrophobic amino acids [26; 27], so its activity is lower.

In the future, to study the effect of enzymes on the biological degradation of films, they were included in the gelatinglycerin films.

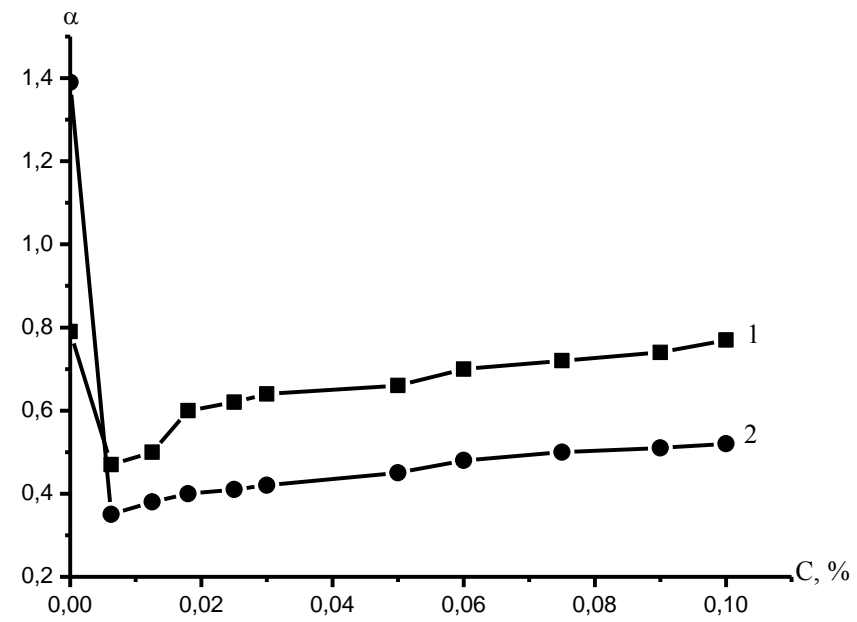

Figure 2: Dependence of the specific activity of pepsin (1) and chymosin (2) from concentration

Figures 3-5 show curves of changes in the strength, modulus of elasticity and deformation of films depending on the concentration of enzymes. As can be seen from Figures 3 and 4 , when the concentration of enzymes increases, the values of strength and modulus of elasticity decrease. However, the curves of changes in the strength and modulus of elasticity of films (Figures 3 and 4) at a low concentration of enzymes $0.01 \%$ have maximum values. This can be explained by the fact that at a given concentration, the number of enzymes is not enough for a destructive effect, while the $\mathrm{Fe}$ and $\mathrm{Ca}$ ions that are part of them can have a cross-linking effect on the gelatin macromolecules, binding to amine and carboxyl groups of amino acids. As can be seen from Table 1, the content of these elements in pepsin is much higher than in chymosin. However, a further increase in the concentration of enzymes leads to a decrease in the strength of the films and this effect is more significant in the case of pepsin than in the case of chymosin. This can be justified by the fact that enzymes at these concentrations begin to perform their functions for the decomposition of amino acids in the composition of films. The deformation values, on the contrary, increase as the concentration of enzymes increases (Figure 5). Increasing the deformation of the films, in turn, contributes to the decomposition of the films.

Thus, the addition of enzymes in the gelatin films reduces the strength and modulus of elasticity, but increases the deformation of the films. As a result, the films become soft and prone to decomposition.

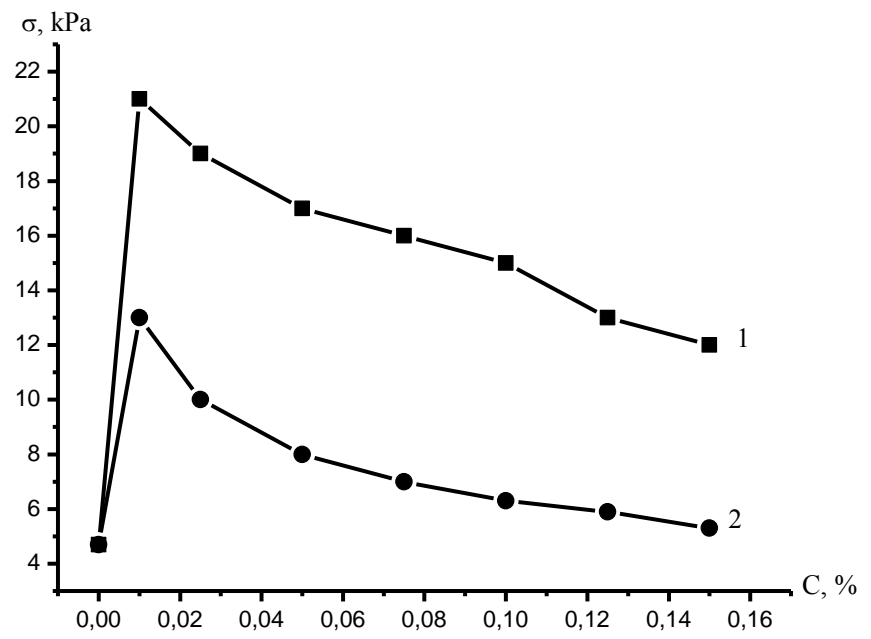

Figure 3: Dependence of the strength of gelatin-glycerin films on the concentration of pepsin (1) and chymosin (2)

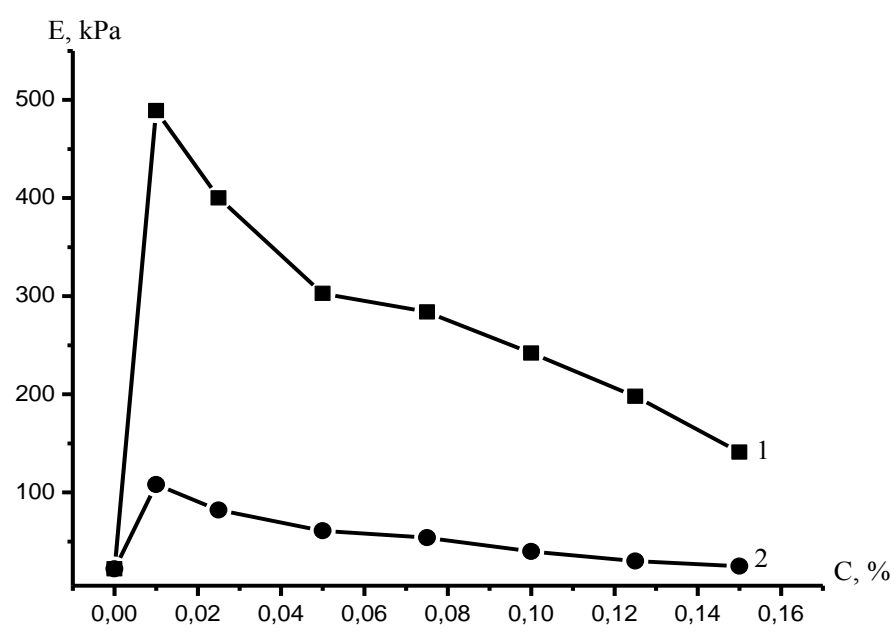

Figure 4: Dependence of the elastic modulus of gelatinglycerin films on the concentration of pepsin (1) and chymosin (2)

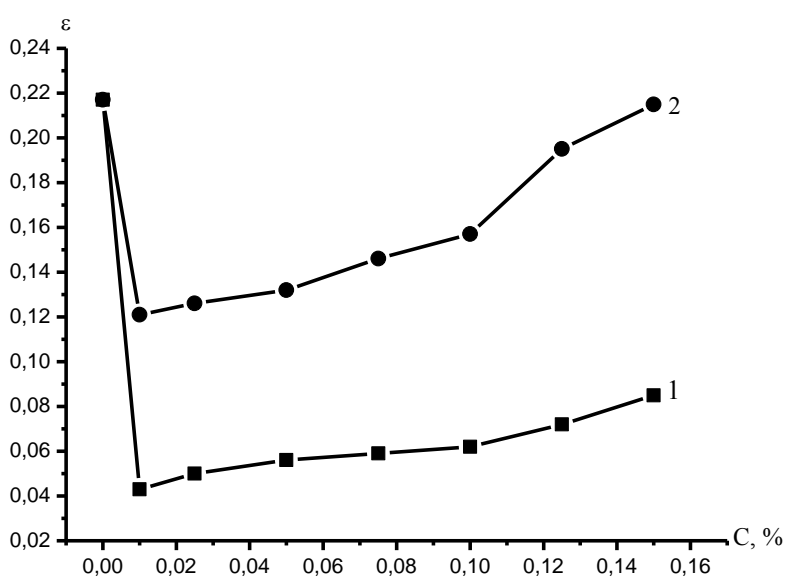

Figure 5: Dependence of the gelatin film deformation on the concentration of pepsin (1) and chymosin (2) 
Table 1: Elemental composition (\%) of original films, enzymes and their mixtures at a mass ratio of gelatin-glycerinenzyme 5: 2: 0.1

\begin{tabular}{|c|c|c|c|c|c|}
\hline Elements & $\begin{array}{c}\text { Gelatin- } \\
\text { glycerin } \\
\text { films }\end{array}$ & Pepsin & $\begin{array}{c}\text { Gelatin- } \\
\text { glycerin- } \\
\text { pepsin } \\
\text { films }\end{array}$ & Chymosin & $\begin{array}{c}\text { Gelatin- } \\
\text { glycerin- } \\
\text { chymosin } \\
\text { films }\end{array}$ \\
\hline Potassium & 0,510 & 23,660 & 5,260 & 0,007 & 0,000 \\
\hline Chlorine & 3,190 & 66,420 & 12,540 & 99,860 & 63,820 \\
\hline Iron & 4,120 & 2,190 & 3,260 & 0,0039 & 1,770 \\
\hline Sulfur & 3,160 & 0,001 & 16,680 & 0,000 & 2,820 \\
\hline Calcium & 81,880 & 7,100 & 62,240 & 0,090 & 31,590 \\
\hline Copper & 0,000 & 0,620 & 0,000 & 0,000 & 0,000 \\
\hline
\end{tabular}

After the addition of enzymes to the composition of films, a significant change in their chemical composition is observed (Table 1). However, it should be noted here that the x-ray fluorescence analysis method determines only those elements that have an atomic mass greater than 30 . Therefore, the table does not contain data on the amount of hydrogen, carbon and oxygen in the films. In addition, it should be noted that the table shows the composition of the original enzymes, but they are included in the gelatin-glycerin films in an amount of 0.1 g. Gelatin-glycerin films and enzymes contain a sufficient (Figure 6). amount of trace elements necessary for living organisms. However, as a result of the interaction of the gelatin-glycerin system with enzymes, the content of $\mathrm{Ca}$ and $\mathrm{Fe}$ decreases, and the amount of chlorine increases. As for sulfur, its content increases sharply after the application of pepsin, but decreases in the case of chymosin. The change in the composition of the films after the application of enzymes may be due to the presence of glutathione in the gelatin, [28]. which plays the role of an antioxidant and interacts with some trace elements of the enzymes.

The glutathione molecule is a combination of three amino acid blocks: cysteine, glycine, and glutamine [29]. The reason for its activity is the presence of sulfur-containing SH-groups. The antioxidant system of glutathione includes three glutathione-dependent enzymes: glutathione peroxidase, glutathione reductase, and glutathione transferase [30]. Therefore, the decrease in the number of trace elements may be due to the fact that glutathione and trace elements are involved in the formation of new enzymes. Trace elements can also participate in the activation of these enzymes [31; 32]. The increase in enzyme activity is further evidence of an increase in the degradation of films.

The destructive effect of enzymes on gelatin-glycerin films is shown by the results of studying the roughness of the films

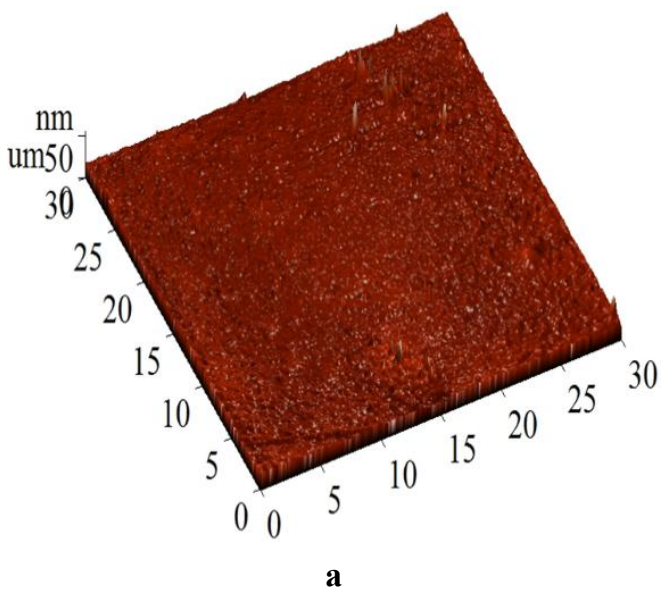

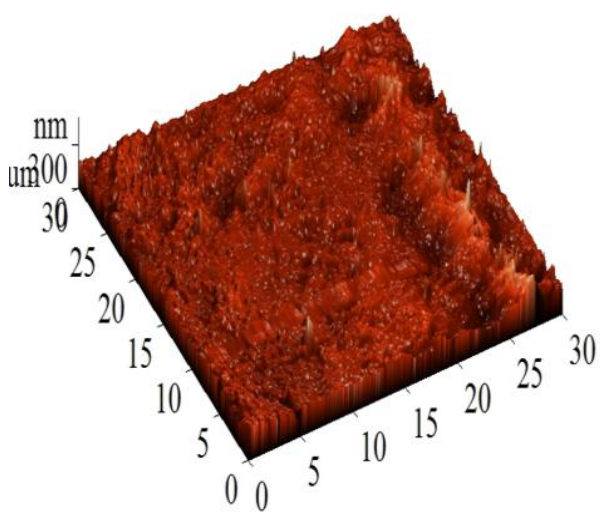

b

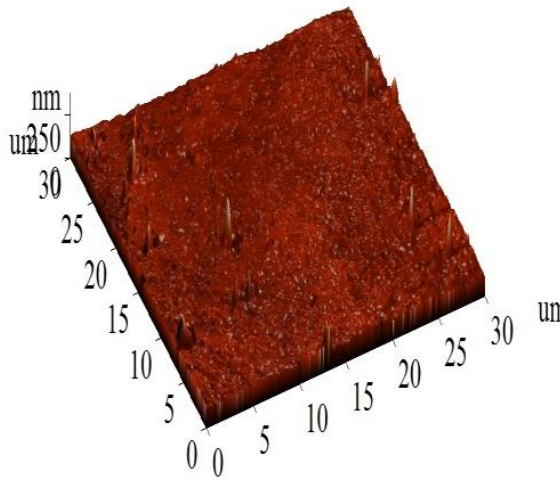

c

Figure 6: Changes in film roughness in systems a) gelatin-glycerin; b) gelatin-glycerin-pepsin; c) gelatin-glycerin-chymosin 
The surface of the original gelatin-glycerin film is rough and small protrusions appear on it, the size of which does not exceed $50 \mathrm{~nm}$. After adding pepsin to the films, the surface roughness increased and the height of the protrusions is within $300 \mathrm{~nm}$.

In the case of gelatin-glycerin-chymosin films, the surface roughness is much less than in the case of gelatin-glycerinpepsin films, the height of the protrusions is within $250 \mathrm{~nm}$. However, it is noteworthy that the number of protrusions when using the enzyme chymosin is much less than when adding pepsin into the films. At the same time, the number and size of protrusions in the case of the gelatin-glycerinchymosin system is greater than in the case of the original film. The increase in the roughness of the films can be explained by their decomposition under the action of enzymes. A sharp increase in the surface roughness of the film in the presence of pepsin indicates the effectiveness of this enzyme in the decomposition of gelatin films.

\section{CONCLUSION}

Biodegradable films based on gelatin and glycerin were obtained. The influence of pepsin and chymosin enzymes on the structural and mechanical properties of films was studied. It is shown that an increase in the concentration of enzymes leads to a decrease in the strength, elastic modulus of the films and an increase in deformation. The presence of enzymes in the films leads to the softening and decomposition of the films. The decomposition of films is determined by the specific activity of enzymes, which in the case of pepsin is higher than that of chymosin. An increase in the roughness of the films in the presence of pepsin and chymosin also indicates the decomposing effect of enzymes on the gelatinglycerin films.

\section{ACKNOWLEDGEMENTS}

The work was carried out as part of the research project No. AP05132126, funded by the Ministry of Education and Science of the Republic of Kazakhstan

\section{REFERENCES}

[1] Bednarski W. I.(1997). // Przem. Spoz. Vol. 51, No. 2. P. 33.http://dx.doi.org//www.sibran.ruee.pdf

[2] Goss R. C., Kalra B. (2002). Metrics to «green» chemistry-which are the best. Green Chemistry, 803. http://dx.doi.org./en/ articlelanding/2002/ divAbstract

[3] Arvanitoyannis, I.J. (1999). Biodegradable polymer composites based on synthetic and natural polymers of various classes, 205. http://dx.doi.org.//springer.com/article/10.1134/S18112 38216010100

[4] Jamshidian, M. Tehrany, E.A., Jacquot, M. Desorby, S. (2010). Poly-lactic acid: production, applications, nanocomposites and release study. Comprehensive Reviews in Food Science and Food Safety. (Vol. 9. - P. 552-571)
[5] http://dx.doi.org.//onlinelibrary.wiley.com/reader/conte nt

[6] Amass W.A. (1998). Review of biodegradable polymers: uses, current developments in the synthesis and characterization of biodegradable polyesters, blends of biodegradable polymers and recent advances in biodegradation studies. Polymer International. (Vol. 47. - P. 89-144)

[7] http://dx.doi.org. //onlinelibrary.wiley.com

[8] Filipovich T.A., Zubets I.V. (2011). Biodegradable polymer packaging materials are an alternative to traditional polymers. Health and environment, 156-162. http://dx.doi.org.biorazlagaem-e-polimer-sovremennoesostoyanie-i-perspektiv-ispolzovaniya.pdf

[9] Vildanov F.Sh., Latypova F.N., Krasutsky P.A., Chanyshev R.R. (2012). Biodegradable polymers, current state and prospects of use // 135-139. http://dx.doi.org.https://www.elibrary.ru/item.asp?id

[10] Bolotova, K.S. Novozhilov, E.V (2015). Application of enzyme technologies to improve the environmental safety of pulp-and-paper production, Chemistry of plant raw materials. (ed. no. 3. - P. 5-23).

[11] http://dx.doi.org//journal.asu.ru/cw/article/view/575

[12] Kuraishi C., Yamazaki, K. Susa, Y. (2001). Its utilization in the food industry, 221-246. http://dx.doi.org://www.tandfonline.com/doi/abs

[13] Collar, C. (2000). Effects of enzyme associations on bread dough performance. Food Sci. Technol. Int. (Vol. 6.- P. 217-226.)

[14] Liang, J.F. (2000). Biomedical application of immobilized enzymes (Vol. 89. - P. 979-990.) http://dx.doi.org:paper.edu.cn/scholar/showpdf

[15] Lei, X.G. (2001) Biotechnological development of effective phytases for mineral nutrition and environmental protection / X.G. Lei, C. H. Stahl // Appl. Microbiol. Biotechnol. (Vol.57. - P. 474-481.)

[16] Schmid, J. (2001) Industrial biocatalysis today and tomorrow (Vol. 409. - P. 258-268.) http://dx.doi.org:paper.edu.cn/scholaZffqfjkhlr/showpd $\mathrm{f}$

[17] Dixon, M. Webb, E. (1982) Enzymes.

[18] Khokhlov, A.S. (1969) Chemical regulators of biological processes / A. S. Khokhlov, Yu.A. Ovchinnikov.

[19] Andren, A. (1992). Production of prochymosin, pepsinogen and progastricsin, and their cellular and intracellular localization in bovine abomasal mucosa, (Vol. 52, 65-70.)

[20] Burdina E.G., Mayorova E.M., Grigorieva E.V., Timofeyeva I.I., Minushkin O.N. (2006). Gastrin-17 and pepsinogen $I$ in assessing the state of the gastric mucosa, Russian medical journal. ( ed. 2. - P. 9-11).

[21] Houen G., Madsan M., Harlow K.W., Lonblad P., Foltmann B., (1996). The primary structure and enzymic properties of porcine prochymosin and chymosin, Int. J. Biochem. Cell. Biol. (Vol.28, 667675.)

[22] Polkovnikova M.V., Azolkina L.N. (2012). Research of properties of various milk-converting enzymes // Altai 
state technical University,73-77.

[23] Volosova E.V., Bezgina Yu.A., Pashkova E.V., Shipulya A.N., Belik E.V. (2016). Spectrophotometric method for determining the proteolytic activity of enzymes immobilized in the structure of biopolymers // Advances in current natural sciences. (ed. no. 4, pp. 18-22.)

[24] Rimareva L.V., Overchenko M.B., Ignatova N.I., Abramova I.M. (2008) Theoretical and practical basis for fermentative catalysis of polymers of grain raw materials in spirit production. Other engineering and technologies. (Vol.№3. 4-9.)

[25] Solomintsev M.V., Mogilny M.P.(2009). / Determination of the activity of proteolytic enzyme inhibitors in food products/ / Izvestiya vuzov. Food technology. - 2009. - № 1. - p. 13-15.

[26] Dijck, P. W. M.(1999). Chymosin and phytase. Made by genetic engineering (No. 10 in a series of articles to promote a better understanding of the use of genetic engineering) / P.W.M. Dijck // J. Biotechnol. Vol. 67, № 10. - P. 77-80.

[27] Chubanova, S.V. Semenchukova, E.A. Valentovich, L.N. (2018). Proteolytic enzymes used in cheese making. Biotechnologies for medicine and industry. (Vol. 10, Pp. 403-438.)

[28] Tolpygina O.A. (2012). The role of glutathione in the antioxidant defense system. (ed. no. 2 (84). Pp. 178180).

[29] Smirnov L.P., Sukhovskaya I.V. (2014). Role of glutathione in functioning of antioxidant defense and biotransformation systems // Scientific notes of Petrozavodsk State University, Biology. (ed. no. 6. Pp. 34-38.)

[30] Kulinsky V.I., Kolesnichenko L.S. (2009). Glutathione System. Synthesis, transport, glutathione transferase, glutathione peroxidease. Biomed.chemistry. (Issue 3. Pp. 255-277.)

[31] Deponte M.(2013). Glutathione catalysis and the reaction mechanisms of glutathione-dependent enzymes. Biochimica et Biophysica Acta (BBA) General Subjects. 1830(5):3217-3266. DOI: https://doi.org/10.1016/j. bbagen.2012.09.018.

[32] Galano A., Alvarez-Idaboy J.R. (2011). Glutathione: mechanism and kinetics of its non-enzymatic defense action against free radicals, RSC Advances, Pp.17631771 . 